\begin{tabular}{|l|l|l||}
\hline \multicolumn{2}{|c|}{ PublisherInfo } \\
\hline \hline PublisherName & $:$ & BioMed Central \\
\hline \hline PublisherLocation & $:$ & London \\
\hline \hline PublisherImprintName & $:$ & BioMed Central \\
\hline \hline
\end{tabular}

\title{
Rax2 marks the spot
}

\begin{tabular}{|l|l|l||}
\hline \multicolumn{2}{|c|}{ ArticleInfo } \\
\hline \hline ArticleID & $:$ & 3861 \\
\hline \hline ArticleDOI & $:$ & $10.1186 /$ gb-spotlight-20001213-03 \\
\hline \hline ArticleCitationID & $:$ & spotlight-20001213-03 \\
\hline \hline ArticleSequenceNumber & $:$ & 298 \\
\hline \hline ArticleCategory & $:$ & Research news \\
\hline ArticleFirstPage & $:$ & 1 \\
\hline \hline ArticleLastPage & $:$ & 2 \\
\hline \hline & & RegistrationDate : 2000-12-13 \\
ArticleHistory & $:$ & OnlineDate \\
\hline \hline ArticleCopyright & $:$ & BioMed Central Ltd2000-12-13 \\
\hline \hline ArticleGrants & $:$ & \\
\hline \hline ArticleContext & $:$ & 130591111 \\
\hline \hline
\end{tabular}




\section{William Wells}

Email: wells@biotext.com

Haploid yeast cells bud next to the site of the previous division (axial pattern), but diploid yeast cells bud from their poles (bipolar pattern). In the 8 December Science, Chen et al. propose that the Rax 2 protein marks the cortex to provide a landmark for bipolar budding (Science 2000, 290:1975-1978). Rax2 is an integral membrane protein, discovered following a hunt for mutants defective in bipolar budding. Late in the cell cycle, Rax2 protein localizes to rings associated with division sites. These rings persist long after production of the protein has ceased. Induction and repression experiments show that the marks are stable, and that existing, localized protein does not shift to new poles or division sites. Rax 2 therefore represents a form of long-lasting, epigenetic inheritance. Its discovery suggests that heritable protein marks at the cell cortex may contribute to the development of tissue architecture in higher eukaryotes.

\section{References}

1. Patterns of bud-site selection in the yeast Saccharomyces cerevisiae.

2. Science, [http://www.sciencemag.org/] 